\title{
Novel Diazole/Triazole and Dibenzothiophene Dioxide Containing Pentacyclic Systems with Promising Biological Activities
}

\author{
Mamuka Maisuradze*, Giorgi Phalavadishvili, Nana Gakhokidze, \\ Manana Matnadze, Sofo Tskhvitaia, Elene Kalandia \\ Department of Chemical and Biological Technology, Georgian Technical University, Tbilisi, Georgia \\ Email: ${ }^{\star}$ m_maisuradze@gtu.ge
}

How to cite this paper: Maisuradze, M., Phalavadishvili, G., Gakhokidze, N., Matnadze, M., Tskhvitaia, S. and Kalandia, E. (2017) Novel Diazole/Triazole and Dibenzothiophene Dioxide Containing Pentacyclic Systems with Promising Biological Activities. International Journal of Organic Chemistry, 7, 34-41. https://doi.org/10.4236/ijoc.2017.71004

Received: December 24, 2016

Accepted: January 22, 2017

Published: January 25, 2017

Copyright ( $\odot 2017$ by authors and Scientific Research Publishing Inc. This work is licensed under the Creative Commons Attribution International License (CC BY 4.0).

http://creativecommons.org/licenses/by/4.0/

\begin{abstract}
The aim of the current work is to synthesize the new heterocyclic pentacyclic condensed systems that combine benzothiophen and benzimidazole/triazole into one molecule. The dibenzothiophene was taken as an initial compound and by consistent "extension" was annihilated the imidazole and triazole nucleuses. As a result two new pentacyclic systems were produced: $3 \mathrm{H}-, 7 \mathrm{H}$-diimidazole[4,5-b][5,4-g] dibenzothiophene-5,5-dioxide and 3H-, 7H-ditriazole[4,5-b][5,4-g] dibenzothiophene-5,5-dioxide with the promising antimicrobial activity. Their spectral characteristics were studied.
\end{abstract}

\section{Keywords}

Dibenzothiophene Dioxide, Imidazole, Triazole, Pentacyclic Systems

\section{Introduction}

The world medical practice confirms that the microorganisms and viruses are becoming more and more dangerous to humans. It is impossible to create a vaccine against all infectious diseases. The pathogenic and conditionally pathogenic strains of bacteria causing the infection processes are characterized by a large number of genetic resistance as well as residence in adverse conditions. These genetic monsters represent the products of selection at those massively used antimicrobial and antiviral drugs. Therefore the antimicrobial drugs are periodically changing.

Therefore the synthesis of new compounds and their antimicrobial and antiviral activities study become very important.

The synthesis of the biologically active compounds on the base of heterocyclic 
compounds is one of the main directions in the search of new drugs. Substances containing heterocyclic fragments quantitatively rank the first in the arsenal of drugs (60\%-over). Because the creation of new drug is very important chemical modification of a known physiologically active molecule, which also means combination of two or more pharmacologically active molecules in one molecule that can promote the increase of biological activity of the new molecule and expand the spectrum of its pharmacological action. This article involves the integration into a single molecule of biologically active fragments, such as benzimidazole/benzotriazole on the one hand and benzothiophene on the other hand. Each of these compounds is characterized by a high biologically, especially antiviral and antifungal activity [1] [2] [3] [4] [5].

\section{Results and Discussion}

In our previous works were successfully synthesized tetracyclic systems on the base of benzimidazole/benzotriazole and benzothiophene [6] [7] [8] [9] [10]. The synthesized compounds revealed high antimicrobial activity in the preliminary study. The current study aimed to create pentacyclic systems where two imidazole/triazole nucleuses would be annihilated with the tricycle system of thiophene.
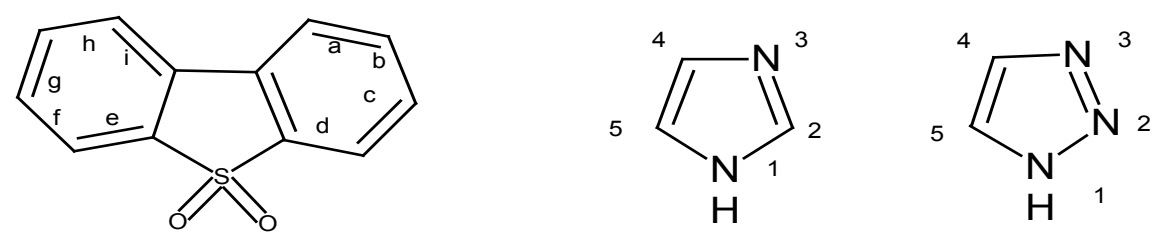

The dibenzothiophene (1) was taken as an initial compound and after oxygenation-dibenzothiophene-5,5-dioxide(2) was received [11] (Figure 1). By nitration of compound (2) was received 3-nitro-(3) and 3,7-dinitrodibenzothiophene-5,5-dioxide (4) in relation of $10 \%$ - 75\% [12]. The 3,7-diaminodibenzothiophene (5) was received from compound (4) by restoring in hydrochloric acid using the zinc dust. The reaction is underway for 40 - 45 minutes in $31 \%$ hydrochloric acid with the addition of zinc dust in small portions at boiling conditions. It should be noted that of the reduction reaction is not running at other conditions (Nickel-Rene-hydrazine hydrate) or going with a minor yield (zinc chloride and hydrochloric acid-24\%yield). The 3,7-diacetamidodibenzo-thiophene-5,5-dioxide (6) was received from compound (5) by acylation in acetic acid at boiling condition using acetic anhydride and with consequent nitration (7) with nitric agentnitric and sulfuric acids $\left(1.57 \mathrm{ml} \mathrm{H}_{2} \mathrm{SO}_{4}, \mathrm{~d}=1.84\right.$ and $5.1 \mathrm{ml}$ $\mathrm{HNO}_{3} ; \mathrm{d}=1.5$ ) and again reduction the 2,8-diamino,-3,7-diacetamidodibenzothiophenes (8) were received. By hydrolyzing of compound (8) by $\mathrm{KOH}$ aqueous solution at ethanol area and boiling conditions was received 2,3,7,8-tetra-aminodibenzothiophene5,5-dioxide (9). The received tetraamine is the initial compound for further extension of imidazole and triazole. Imidazole containing 

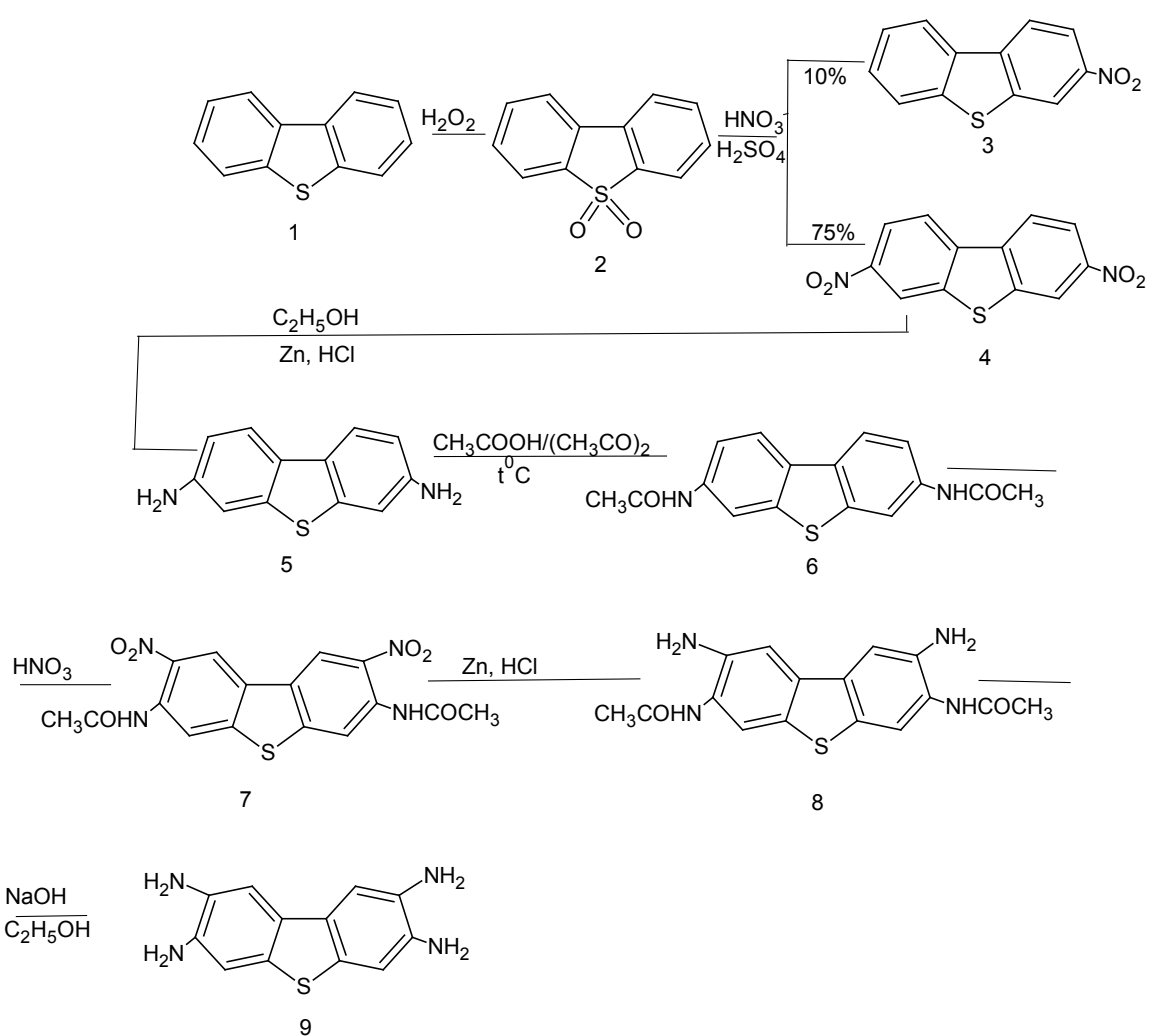

Figure 1. Synthesis of 2,3,7,8-tetra-aminodibenzothiophene-5,5-dioxide.

pentacyclic system 3H-, 7H-diimidazole[4,5-b][5,4-g]dibenzo-thiophene-5,5dioxyde (10) was obtained from tetraamines by condensation with formic acid at the presence of a catalytic amount of hydrochloric acid at the modified Phillips reaction conditions. Triazole containing pentacyclic system $3 \mathrm{H}-$, $7 \mathrm{H}$-ditriazo-le [4,5-b][5,4-g]dibenzothiophene-5,5-dioxide (11) was obtained by reaction of hydrochloric acid and sodium nitrite with diamine (Figure 2).

The originally synthesized compounds were tested by IR, 1H-PMR and massspectroscope methods.

$\mathrm{NH}_{2}$-groups signal of IR spectra of compounds (8), (9) were observed at 3400 - $3300 \mathrm{~cm}^{-1}$ area, $\mathrm{NH}$ - groups signal of IR spectra of compounds (6), (7), (8), (10), (11) were observed at $3440-3420 \mathrm{~cm}^{-1}$ area. $\mathrm{SO}_{2}$-group signals of IR spectra of all the compounds were observed at $1157-1140 \mathrm{~cm}^{-1}$ area. $\mathrm{CH}_{3}$-group signals of IR spectra of compounds (6), (7), (8) were observed at 3245 - 3240 $\mathrm{cm}^{-1}$ area. $\mathrm{C}=\mathrm{O}$-group signals of IR spectra of compounds (6), (7), (8) were observed at $1704-1700 \mathrm{~cm}^{-1}$ area. $\mathrm{C}=\mathrm{N}$-group signals of IR spectra of these substances also observed at $1550-1535 \mathrm{~cm}^{-1}$ area. Mass spectroscopy data matches the molecular weights of synthesized compounds. 1H-PMR spectroscopy data also confirm the structure of obtained compounds.

\section{Experiment}

The electronic absorption spectrawere recorded on the device "Varian" Cary 100 UV-Vis spectrophotometer. IR spectra were recorded on spectrum meter 


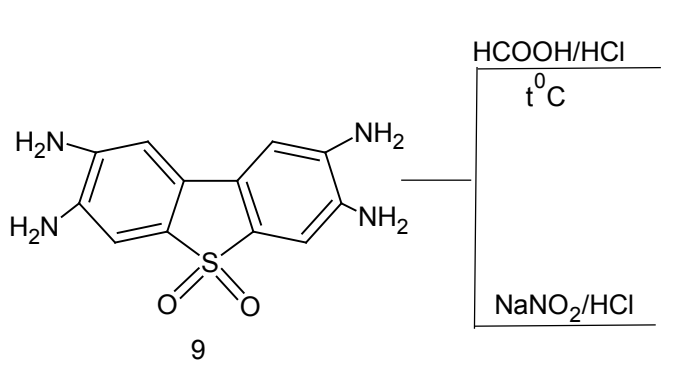

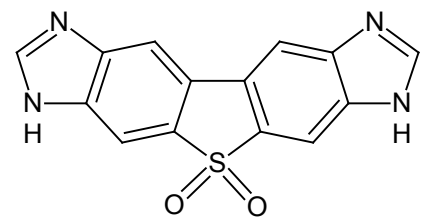

10

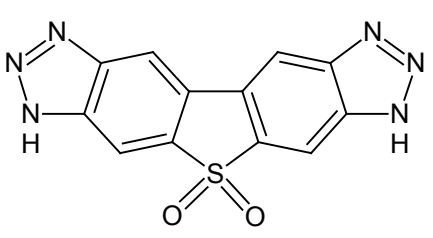

11

Figure 2. Synthesis of 3H-, 7H-diimidazole[4,5-b][5,4-g]dibenzo-thiophene-5,5-dioxyde and $3 \mathrm{H}$-, 7H-ditriazole[4,5-b][5,4-g]dibenzo-thiophene-5,5-dioxyde.

“Thermo Nicolet" Avatar 370. ${ }^{1} \mathrm{H}$ NMR spectra were recorded on spectrometer "Bruker" WM-400 (400 MHz) in DMSO-d $\mathrm{d}^{6}$, TMS internal standard. Elemental analysis was performed on the analyzer HP-165B CHN. Melting point was defined on the apparatus "Mel-Temp 3.0". Control of the reaction and purity of the products was carried out on the plates

Dibenzothiophene-5,5-dioxide (2). $18.4 \mathrm{~g}$ (0.1 mole) dibenzothiophene (1) was mixed in $100 \mathrm{ml}$ glacial acetic acid and then heated. At the boiling and stirring conditions $30 \mathrm{ml}$ of hydrogen peroxide with drops was added and white colored crystals were precipitated. The reaction area was sustained under boiling and stirring processes for 1 hour and was added $10 \mathrm{ml}$ of hydrogen peroxide and boiled for 30 minutes again. The mixture was leaved for 24 hours and filtrated. Filter paper remains monoxide and dioxide precipitates out of the filtrate that was processed with water and dried in the neutral area and was crystallized with $96 \%$ ethanol. It was received $20.6 \mathrm{~g}$ dibenzothiophene-5,5-dioxide(2). $\mathrm{M}=216$; $\mathrm{C}_{12} \mathrm{H}_{8} \mathrm{O}_{2}$; Yield: $95.3 \%$. $\mathrm{T}_{\text {m.p }}=231^{\circ} \mathrm{C}$, Lit. $\mathrm{T}_{\text {m.p }}=232^{\circ} \mathrm{C}-233^{\circ} \mathrm{C}$ [11]. White needle-like crystals; control-chloroform/ethyl acetate-3/1.

3,7-dinitrodibenzothiophene-5,5-dioxide(3) and 3-nitro-dibenzothiophene-5,5-dioxide (4). $11.4 \mathrm{~g}$ (0.05 moles) dibenzothiophene-5,5-dioxide was dissolved in $40 \mathrm{ml}$ of concentrated sulfuric acid at $0^{\circ} \mathrm{C}$ temperature. Then was added drops of $34.2 \mathrm{ml}$ smoking nitric acid $(\mathrm{d}=1.5)$. The temperature of $60^{\circ} \mathrm{C}$ $70^{\circ} \mathrm{C}$ grades was kept. This mixture was allowed to cool and poured into ice water. The yellow precipitation was filtered, washed by water, dried and crystallized in acetone. During the crystallization in filtrate was precipitated 3,7-dinitrodibenzothiophen-5,5-dioxide (3), while the filter remains in the 3-dinitrodibenzothiophen-5,5-dioxide (4). As a result was obtained $12.2 \mathrm{~g} 75.5 \%$ 3,7-dinitro dibenzothiophene-5,5-dioxide (3) lemon color crystals; $\mathrm{M}=306 ; \mathrm{C}_{12} \mathrm{H}_{6} \mathrm{~N}_{2} \mathrm{O}_{6} \mathrm{~S}$ $\mathrm{C}_{12} \mathrm{H}_{7} \mathrm{NO}_{4} \mathrm{~S}$; Control-chloroform/ethyl acetate-3/1;(3)- $\mathrm{T}_{\mathrm{m} . \mathrm{p}}=287^{\circ} \mathrm{C}-288^{\circ} \mathrm{C}$. Lit. $\mathrm{T}_{\mathrm{m} . \mathrm{p}}=290^{\circ} \mathrm{C}[12]$.

3,7-diaminodibenzothiophene-5,5-dioxide(5). $12.2 \mathrm{~g}$ (0.039 moles) 3,7- dinitro-dibenzothiophene-5,5-dioxide (3) was mixed with $481 \mathrm{ml} 96 \%$ ethanol and

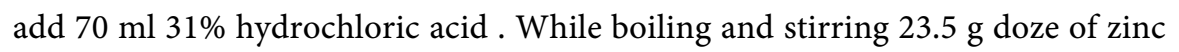


dust was added. Yellow reaction area eventually became transparent red. The reaction took 40 - 45 minutes. Reaction area was filtered, added water and the red precipitation was obtained. The precipitation was filtered and orange filtrate was processed with $40 \%$ solution of sodium alkali and was filtrated again. The diamine from the filtrate was extracted with ethyl acetate. After ethylacetate evaporation was obtained compound (5). The diamines were extracted from filter remaining salts with alcohol, then were precipitated with water, filtered again, washed up to neutral area and dried at room temperature. After crystallization with $96 \%$ ethyl alcohol yellow-green color $9.5 \mathrm{~g}$ crystals were appeared. $\mathrm{M}$ $=246 ; \mathrm{C}_{12} \mathrm{H}_{10} \mathrm{~N}_{2} \mathrm{O}_{2} \mathrm{~S} ;$ Control-chloroform. Yield: $96.9 \% \mathrm{~T}_{\mathrm{m} \cdot \mathrm{p}}=324^{\circ} \mathrm{C}-326^{\circ} \mathrm{C}$. Lit. $\mathrm{T}_{\mathrm{m} . \mathrm{p}}=327^{\circ} \mathrm{C}[12]$.

3,7-diacetamidodibenzothiophene-5,5-dioxide (6). $1.1 \mathrm{~g}$ (0.004 mole) of 3,7-diaminodibenzothiophene-5,5-dioxide (5) was added $68.75 \mathrm{ml}$ ( 0.3 mole) of glacial acetic acid and boiled under stirring condition. The drops of $0.75 \mathrm{ml}(0.03$ mole) acetic anhydride was added and beige-yellow color crystals was precipitated. The mixture was kept at stirring and boiling conditions for 30 minutes, was hotly filtered and washed with water up neutral reaction. Then was dried at room temperature and crystalized with alcohol. Control-ethyl acetate: Ether 3:1. Yields: 1.4 g. $95 \% . \mathrm{T}_{\mathrm{m} . \mathrm{p}}=337^{\circ} \mathrm{C}-339^{\circ} \mathrm{C} ; \mathrm{M}=330$; Anal. Calc. For. C-58.17; H4.27; N-8.48; S, 9.71\%. $\mathrm{C}_{16} \mathrm{H}_{14} \mathrm{~N}_{2} \mathrm{O}_{4}$ S; Found: C- 58.04; H-4.61; N-8.27; S-9.421\%. IR $(\mathrm{KBr}) v_{\max }\left(\mathrm{cm}^{-1}\right): 3440(\mathrm{NH}) ; 3245\left(\mathrm{CH}_{3}\right) ; 1704(\mathrm{C}=\mathrm{O}) ; 1550(\mathrm{CN}) ; 1157\left(\mathrm{SO}_{2}\right)$. ${ }^{1} \mathrm{H}$ NMR (400 MHz, DMSO- $d_{6}$ ) (ppm): 2.09 (3H, s, $\left.J=2.09, \mathrm{COCH}_{3}-2^{1}, 6^{1}\right), 8.08$ $\left(1 \mathrm{H}, \mathrm{s}, J_{9.1}=8.13, J_{7.8}=8.13, J_{8.5}=0.91, J_{9.3}=0.91, \mathrm{H}-8.9\right), 8.17\left(1 \mathrm{H}, \mathrm{s}, J_{1.3}=2.33\right.$, $\left.J_{7.5}=2.33, J_{1.9}=8.13, J_{7.5}=2.23, \mathrm{H}-1,7\right), 8.44\left(1 \mathrm{H}, \mathrm{s}, J_{3.1}=2.33, J_{5.7}=2.33, J_{3.9}=\right.$ $\left.0.91, J_{5.8}=0.90, \mathrm{H}-3,5\right), 9.89\left(1 \mathrm{H}, \mathrm{bs}, \mathrm{NH}-2^{1}, 6^{1}\right) . \mathrm{m} / \mathrm{z}: 330.07$ (100.0\%), 331.07 (18.4\%), 332.06 (4.5\%), 332.07 (2.5\%).

2,8-dinitro-3,7-diacetamidodibenzothiophene-5,5-dioxide(7). $2.1 \mathrm{~g}(0,006$ mole) 3,7-diamino acyl-dibenzothiophene-5,5-dioxide is placed in three-neck flask, (that is equipped with stirring appliance, drop funnel and thermometer) and was added $32 \mathrm{ml}$ ( 0.7 mole) glacial acetic acid. Then was added mix of sulfur acid and nitric acid $\left(1.57 \mathrm{ml} \mathrm{H}_{2} \mathrm{SO}_{4}, \mathrm{~d}=1.84\right.$ and $\left.5.1 \mathrm{ml} \mathrm{HNO}_{3} ; \mathrm{d}=1.5\right)$ at stirring conditions and $60^{\circ} \mathrm{C}-70^{\circ} \mathrm{C}$ temperature for 15 minutes. The reaction mass wais moved into glacial glass and reddish crystals was precipitated. The precipitation was filtrated, washed, dried and crystallized into the ethylacetate. $M=420$; Control-chloroform/ethylacetate/ether 1:2:1. Yields: 2.5 g. 97\%; Reddish crystals. $\mathrm{T}_{\text {m.p }}=192^{\circ} \mathrm{C}-193^{\circ} \mathrm{C}$. Anal. Calc. For. $\mathrm{C}_{16} \mathrm{H}_{12} \mathrm{~N}_{4} \mathrm{O}_{8}$ S. C- 45.72; H-2.88; N- 13.33; S-7.63\%. Found: C-45.92; H-2.67; N-13.25; S-7.47\%. IR (KBr) $v_{\max }\left(\mathrm{cm}^{-1}\right): 3440$ (NH) $3245\left(\mathrm{CH}_{3}\right) ; 1700(\mathrm{C}=\mathrm{O}) ; 1535(\mathrm{CN}) ; 1532\left(\mathrm{NO}_{2}\right) ; 1140\left(\mathrm{SO}_{2}\right) .{ }^{1} \mathrm{H}$ NMR $\left(400 \mathrm{MHz}, \mathrm{DMSO}-d_{6}\right)(\mathrm{ppm}): 2.11\left(3 \mathrm{H}, \mathrm{s}, J=2.09, \mathrm{COCH}_{3}-2^{1}, \mathrm{COCH}_{3}-6^{1}\right), 8.64$ $\left(1 \mathrm{H}, \mathrm{s}, J_{3,9}=0.71, J_{5,8}=0.71, \mathrm{H}-3.5\right), 9.02\left(1 \mathrm{H}, \mathrm{d}, J_{9,3}=0.71, J_{8,5}=0.71, \mathrm{H}-8.9\right)$, 10.41(1H, bs, NH-2 $\left.{ }^{1}, 6^{1}\right) . \mathrm{m} / \mathrm{z}: 420.04$ (100.0\%), 421.04 (18.5\%), 422.03 (4.5\%), 422.04 (3.5\%), 421.03 (1.5\%)

2.8-diamine-3,7-diacetamidodibenzothiophene-5,5-dioxide (8) was synthesized similarly as 3,7-diamino-dibenzothiophene-5,5-dioxide (5). Yields: $1.2 \mathrm{~g}$ 
$0.40 \% ; \mathrm{T}_{\mathrm{m} . \mathrm{p}}=236^{\circ} \mathrm{C}-238^{\circ} \mathrm{C} . \mathrm{M} 276$. Anal. Calc. For. $\mathrm{C}_{16} \mathrm{H}_{16} \mathrm{~N}_{4} \mathrm{O}_{4} \mathrm{~S}$. C-52.16; H4.38; N-20.28; S-11.60\%. Found: C-52.25; H-4.22; N-20.31; S-11.50\%. IR (KBr) $v_{\max }\left(\mathrm{cm}^{-1}\right): 3440(\mathrm{NH}) ; 3300\left(\mathrm{NH}_{2}\right) ; 3240\left(\mathrm{CH}_{3}\right) ; 1700(\mathrm{C}=\mathrm{O}) ; 1530(\mathrm{CN}) ; 1150$ $\left(\mathrm{SO}_{2}\right) .{ }^{1} \mathrm{H} \mathrm{NMR}\left(400 \mathrm{MHz}, \mathrm{DMSO}-d_{6}\right)(\mathrm{ppm}): 2.01\left(3 \mathrm{H}, \mathrm{s}, J_{3}=2.09,-\mathrm{COCH}_{3}-2^{1}\right.$, $\left.-\mathrm{COCH}_{3}-6^{1}\right), 6.29\left(1 \mathrm{H}, \mathrm{s}, \mathrm{NH}-2^{1}, 6^{1}\right), 6.43(2 \mathrm{H}, \mathrm{s}, \mathrm{NH}-1.7) .7 .87\left(1 \mathrm{H}, \mathrm{d}, J_{3.9}=0.72\right.$, $\left.J_{5.8}=0.72, \mathrm{H}-3.5\right), 8.10\left(1 \mathrm{H}, \mathrm{d}, J_{9.3}=0.72, J_{8.5}=0.72, \mathrm{H}-8.9\right) . \mathrm{m} / \mathrm{z}: 276.07(100.0 \%)$, 277.07 (15.5\%), 278.06 (4.5\%), 278.07 (1.5\%).

2,3,8,7-tetraaminodibenzothiophenes-5,5-dioxide (9). 0.6 g (0.002 mole) 2.8-diamino-3,7diaminoacyl-dibenzothiophene-5,5-dioxide (8) was added into $20 \mathrm{ml}$ ethanol and $5 \mathrm{~g} \mathrm{KOH}$ dissolved in $20 \mathrm{ml}$ water. It was kept at stirring and boiling conditions for 30 minutes. Violet crystals were filtrated, washed until neutral reaction and dried. Then it is crystallized in ethyl acetate. Yields: $0.38 \mathrm{~g}$. $\mathrm{M}=276$; Control-benzol/ether 3:1; 42\%; violet crystals. $\mathrm{T}_{\mathrm{m} . \mathrm{p}}=225^{\circ} \mathrm{C}-227^{\circ} \mathrm{C}$. M276. Anal. Calc. For. $\mathrm{C}_{12} \mathrm{H}_{12} \mathrm{~N}_{2} \mathrm{O}_{2} \mathrm{~S}$. C-52.16; H-4.38; N-20.28; S-11.60\%. Found: C-52.41; H-4.42; N-20.18; S-11.52\%. IR (KBr) $v_{\max }\left(\mathrm{cm}^{-1}\right): 3400,3300$ $\left(\mathrm{NH}_{2}\right) ; 1150\left(\mathrm{SO}_{2}\right) .{ }^{1} \mathrm{H}$ NMR $\left(400 \mathrm{MHz}, \mathrm{DMSO}-d_{6}\right)(\mathrm{ppm}): 4.87\left(2 \mathrm{H}, \mathrm{d}, \mathrm{NH}_{2}-\right.$ 2,3,6,7), $7.08\left(1 \mathrm{H}, \mathrm{d}, J_{3.9}=0.71, J_{5.8}=0.71, \mathrm{H}-3.5\right), 7.66\left(1 \mathrm{H}, \mathrm{d}, J_{8.5}=0.71, J_{9.3}=\right.$ 0.71, H-8.9). m/z: 276.07 (100.0\%), 277.07 (15.5\%), 278.06 (4.5\%), 278.07 (1.5\%).

\section{H-, 7H-diimidazole [4,5-b],[5,4-g]-dibenzothiophene-5,5-dioxide (10)}

$0.2 \mathrm{~g}$ tetraamine ( 0.001 mole) (9) was placed in the three-necked flask (that is equipped with dropping funnel and reflux condenser) and added $1 \mathrm{ml}$ (0.04 mole) of formic acid and $1 \mathrm{ml}$ ( 0.04 mole) of $31 \%$ hydrochloric acid and suspension was boiled during 30 minutes. By adding of $50 \mathrm{ml}$ water obtained suspension was alkalized by ammonium hydroxide, till the ammonia odor appeared. Formed brown crystals were filtered, washed until neutral conditions, dried and crystallized in acetone. Control-ethyl acetate/hexane/ether 5:1:3. Yields: $0.15 \mathrm{~g}$. $70 \%$; Brown crystals. $\mathrm{T}_{\mathrm{m} . \mathrm{p}}=322^{\circ} \mathrm{C}-324^{\circ} \mathrm{C} . \mathrm{M}$ 296. Anal. Calc. For. $\mathrm{C}_{14} \mathrm{H}_{8} \mathrm{~N}_{4} \mathrm{O}_{2} \mathrm{~S}$. C-56.75; H-2.72; N-18.91; S-10.82\%. Found: C-56.66; H-2.62; N-19.00; S-10.65\%. IR (KBr) $v_{\max }\left(\mathrm{cm}^{-1}\right): 3430,3400(\mathrm{NH}) ; 1150\left(\mathrm{SO}_{2}\right) .{ }^{1} \mathrm{H}$ NMR $(400 \mathrm{MHz}$, DMSO$\left.d_{6}\right)(\mathrm{ppm}): 8.10\left(1 \mathrm{H}, \mathrm{d}, J_{10.8}=0.06, J_{10.6}=0.91, J_{11.4}=0.91, J_{11.2}=0.06, \mathrm{H}-10.11\right)$, $8.42\left(1 \mathrm{H}, \mathrm{d}, J_{4.11}=0.91, J_{6.10}=0.91, \mathrm{H}-4.6\right), 8.53\left(1 \mathrm{H}, \mathrm{d}, J_{2.11}=0.06, J_{8.10}=0.06, \mathrm{H}-\right.$ 2.8), 12.20 (1H, bs, NH-3, NH-7). m/z: 296.04 (100.0\%), 297.04 (16.1\%), 298.03 (4.5\%), 298.04 (1.8\%), 297.03 (1.5\%).

\section{$3 \mathrm{H}-$, 7H-ditriazole[4,5-b][5,4-g] dibenzothiophene-5,5-dioxide (11)}

$0.2 \mathrm{~g}$ tetraamine $(0.0007 \mathrm{~mol})(9)$ was placed in the three-necked flask (that is equipped with dropping funnel and reflux condenser) and added $0.36 \mathrm{ml}$ of hydrochloric acid (31\%) and $4 \mathrm{ml}$ water. The substance is not soluble in hydrochloric acid and was only bulked up. The solution of $0.1 \mathrm{~g}$ sodium nitrite $\left(\mathrm{NaNO}_{2}\right)$ and $0.5 \mathrm{ml}$ water was added at the condition of cooling by cold water and rotation. After the addition of nitrite, the color of mixture turned into brown. Approximately after 10 minutes the color became even lighter. Then the mixture was heated for 30 minutes and then was filtered and washed with cold water. The product was subjected to be recrystallized from acetic acid and was washed with ammonia liquor. Control-ether/hexane/ethyl acetate 5/1/3. Yields: $0.168 \mathrm{~g}$. 
78\%; Brown crystals. $\mathrm{T}_{\mathrm{m} . \mathrm{p}}=346^{\circ} \mathrm{C}-348^{\circ} \mathrm{C} . \mathrm{M}=298$; Anal. Calc. For. $\mathrm{C}_{12} \mathrm{H}_{6} \mathrm{~N}_{6} \mathrm{O}_{2} \mathrm{~S}$. C-48.32; H-2.03; N-28.17; S-10.75\%. Found: C-48.25; H-2.23; N-28.11; S-10.62\%. IR (KBr)) $v_{\max }\left(\mathrm{cm}^{-1}\right): 3420,3390(\mathrm{NH}) ; 1150\left(\mathrm{SO}_{2}\right) .{ }^{1} \mathrm{H}$ PMR $(400 \mathrm{MHz}$, DMSO$\left.d_{6}\right)(\mathrm{ppm}): 8.57\left(1 \mathrm{H}, \mathrm{d}, J_{6,10}=0.91 ; J_{4,11}=0.91 \mathrm{H}-10.11\right), 8.80\left(1 \mathrm{H}, \mathrm{d}, J_{6,10}=0.91\right.$, $\left.J_{4,11}=0.91, \mathrm{H}-4.6\right), 11.82(1 \mathrm{H}$, bs, NH3, NH-7). m/z: 298.03 (100.0\%), 299.03 (13.9\%), 300.02 (4.6\%), $299.02(2.2 \%), 300.03(1.6 \%)$.

\section{Conclusion}

Thus 2,3,7,8-tetramino-dibenzothiophene-5,5-dioxide was received from dibenzothiophene-5,5-dioxide after its consistent transformation that was the initial compound. The pentacyclic heterocyclic condensed systems 3H-, 7H-diimidazolo [4,5-b][5,4-g]dibenzothiophene-5,5-dioxide and 3H-, 7H-ditriazolo [4,5-b] [5,4-g]dibenzothiophene-5,5-dioxide were synthesized at Philips modified reaction conditions and also with sodium nitrate and hydrochloride acid influence. The obtained compounds due to antimicrobial activity of their component cycles represent good starting matrix for getting numerous derivatives by entering different substituents. Derivatives can be obtained not only from synthesized cycles but also from various tetraamines by reaction with condensation agents.

\section{References}

[1] Arulmurugan, S., Kavitha, H.P., Sathishkumar, S. and Arulmozhi, R. (2016) Biologically Active Benzimidazole Derivatives, Mini-Reviews in Organic Chemistry, 12, 178-195.

[2] Chanda, K., Rajasekhar, S., Maiti, B. and Balamurali, M.M. (2016) Synthesis and Medicinal Applications of Benzimidazoles: An Overview. Current Organic Synthesis, 13. (E-Pub Ahead of Print)

[3] Khabnadideh, S., Rezaei, Z., Khalafi-Nezhad, A., Pakshir, K., Roosta, A. and Baratzadeh, Z. (2009) Design and Synthesis of Imidazole and Benzimidazole Derivatives as Antifungal Agents. Anti-Infective Agents, 7, 215-218.

[4] Mentes, E., Yilmaz, F., Beris, F.S., Bekircan, O. and Kahveci, B. (2015) MicrowaveAssisted Synthesis of Some New Benzimidazole Derivatives with Their Antimicrobial Activity. Current Microwave Chemistry, 2, 32-39.

[5] Yurttas, L., Ozkay, Y., Karaca, H., Tunali, Y. and Kaplancıkli, Z.A. (2013) Synthesis and Antimicrobial Evaluation of Some 2,5-Disubstituted Benzimidazole Derivatives. Letters in Drug Design \& Discovery, 10, 486-491. https://doi.org/10.2174/1570180811310060003

[6] Maisuradze, M., Ugulava, G., Bolkvadze, N., Phalavandishvili, G., Gakhokidze, N. and Matnadze, M. (2013) Some New Derivatives of 3H-Benzo (b)Furobenzotriazole. Journal of Chemistry and Chemical Engineering, 7, 621-625.

[7] Maisuradze, M., Khoshtaria, T., Gakhokidze, N. and Kurkovskaia, L. (2008) Synthesis of Benzo[ $b]$ Thieno[3,2-e]Benzimidazoles, First Representatives of a New Heterocyclic System. Chemistry of Heterocyclic Compounds, 44, 1024-1026. https://doi.org/10.1007/s10593-008-0148-8

[8] Maisuradze, M. and Ugulava, G. (2012) The Triazole and Thiophene Containing New Heterocyclic Systems. Journal of Chemistry and Chemical Engineering, 6, 378 383.

[9] Maisuradze, M.G., Ananiashvili, V.O., Gaxokidze, N.Z. and Matnadze, M.M. (2013) 
Some Novel Derivatives of 3H-Benzo[b]Thiophen[3,2-e]Benzimidazole. Chemistry of Heterocyclic Compounds, 48, 1801-1804.

https://doi.org/10.1007/s10593-013-1211-7

[10] Maisuradze, M.G., Ananiashvili, V.O., Gaxokidze, N.Z., Matnadze, M.M. and Tsqvitaia, S.P. (2012) Synthesis of Novel Heterocyclic Systems, Benzo[b]Furobenzimidazoles. Chemistry of Heterocyclic Compounds, 48, 1125-1126.

https://doi.org/10.1007/s10593-012-1112-1

[11] Gilman, H. and Esway, D.L. (1952) The Oxidation of Dibenzo Thiofene and Phenoxathiin with Hydrogen Peroxide. Journal of the American Chemical Society, 74, 2021-2025. https://doi.org/10.1021/ja01128a046

[12] Gullinane, N.M., Davies, C.G. and Davies, G.I. (1936) Substitution Derivatives of Difenilene Sulfide and Difenilenesulfone. Journal of the Chemical Society, 31, 14351437.

Submit or recommend next manuscript to SCIRP and we will provide best service for you:

Accepting pre-submission inquiries through Email, Facebook, LinkedIn, Twitter, etc. A wide selection of journals (inclusive of 9 subjects, more than 200 journals)

Providing 24-hour high-quality service

User-friendly online submission system

Fair and swift peer-review system

Efficient typesetting and proofreading procedure

Display of the result of downloads and visits, as well as the number of cited articles Maximum dissemination of your research work

Submit your manuscript at: http://papersubmission.scirp.org/

Or contact ijoc@scirp.org 